\title{
ANALISIS RASIO KEUANGAN SEBELUM DAN SESUDAH PENERAPAN PERNYATAAN STANDAR AKUNTANSI PEMERINTAHAN NOMOR 13 PADA PUSKESMAS TEGALREJO YOGYAKARTA PERIODE 2016-2017
}

\author{
ANALYSIS OF FINANCIAL RATIOS BEFORE AND AFTER THE \\ APPLICATION OF STATEMENT OF GOVERNMENT ACCOUNTING \\ STANDARDS NUMBER 13 IN TEGALREJO HEALTH CENTER YOGYAKARTA \\ 2016-2017 PERIOD
}

YUMAZAIN IZHHAR YOHAN

Progam Studi Akuntansi, Fakultas Ekonomi, Universitas Negeri Yogyakarta Yumazain97@gmail.com ABDULLAH TAMAN, M.Si., Ak., CA

Staf Pengajar Jurusan Pendidikan Akuntansi Universitas Negeri Yogyakarta

\begin{abstract}
Abstrak: Analisis Rasio Keuangan Sebelum Dan Sesudah Penerapan Pernyataan Standar Akuntansi Pemerintahan Nomor 13 Pada Puskesmas Tegalrejo Yogyakarta Periode 20162017. Penelitian ini bertujuan untuk mengetahui bagaimana Rasio Keuangan ditinjau dari Rasio Likuiditas, Rasio Solvabilitas, Rasio Profitabilitas, dan Rasio Aktivitas sebelum dan sesudah penerapan PSAP Nomor 13 pada Pelaporan Keuangan Puskesmas Tegalrejo Yogyakarta. Metode pengumpulan data yang digunakan adalah dokumentasi. Metode analisis data menggunakan analisis komparatif sederhana pada Pelaporan Keuangan Puskesmas Tegalrejo dengan menggunakan Rasio Keuangan tahun 2016-2017 yang meliputi Rasio Likuiditas, Rasio Solvabilitas, Rasio Profitabilitas, serta Rasio Aktivitas. Hasil penelitian menunjukkan bahwa Rasio Solvabilitas tahun 2016 dan 2017 Puskesmas Tegalrejo Yogyakarta diperoleh hasil bahwa analisis Rasio Likuiditas pada Puskesmas Tegalrejo mengalami penurunan, hasil Rasio Solvabilitas diperoleh meningkat. Sementara hasil Rasio Profitabilitas cenderung mengalami peningkatan, serta rasio aktivitas mengalami penurunan.
\end{abstract}

Kata Kunci: Laporan Keuangan, Penyajian Laporan Keuangan, Rasio Keuangan, Rasio Likuiditas, Rasio Solvabilitas, Rasio Profitabilitas, Rasio Aktivitas.

Abstract : Analysis Of Financial Ratios Before And After The Application Of Statement Of Government Accounting Standards Number 13 In Tegalrejo Health Center Yogyakarta 20162017 Period. This resarch aims to determine how the Financial Ratio is viewed from the Liquidity Ratio, Solvability Ratio, Profitability Ratio, and Activity Ratios before and after the implementation of PSAP Number 13 on the Financial Report of Tegalrejo Public Health Center Yogyakarta. The data collection method used was documentation. The data analysis method used a simple comparative analysis of the Tegalrejo Community Health Center Financial Report used a Financial Ratios of 2016-2017 which includes Liquidity Ratios, Solvability Ratios, Profitability Ratios, and Activity Ratios. The results of the study showed that the Solvability Ratio in 2016 and 2017 in the Tegalrejo Public Health Center Yogyakarta showed that the analysis of the Liquidity Ratio in the Tegalrejo Health Center had decreased, the results of the solvency ratio obtained increased. While the results of Profitability Ratios tend to increase, and the Activity Ratio had decreased.

Keyword: Financial Statements, Presentation of Financial Statements, Financial Ratios, Liquidity Ratios, Solvability Ratios, Profitability Ratios, Activity Ratios. 


\section{JURNAL NOMINAL / VOLUME VIII NOMOR 1 / TAHUN 2019}

\section{PENDAHULUAN}

\begin{abstract}
Menimbang
Undang-Undang

Nomor 1 tahun 2004 mengenai Perbendaharan Negara, dalam rangka peningkatan pelayanan pemerintah kepada seluruh masyarakat dengan memperhatikan prinsip efisiensi dan produktifitas serta instansi satuan kerja tersebut diberikan fleksibilitas dalam pengelolaan keuangan dengan memper-hatikan penerapan praktik-
\end{abstract} praktik bisnis yang sehat guna meningkatkan pelayanan tanpa mengutamakan keuntungan, satuan kerja pemerintahan ditetapkan menjadi lembaga satuan kerja dengan menerapkan pola pengelolaan keuangan Badan Layanan Umum (BLU), Instansi pemerintah pada UU ini agar dapat memberikan pelayanan kepada publik seperti pemberian pelayanan barang atau jasa serta memiliki kontribusi dalam pengelolaan dana khusus serta pengelolaan kawasan dalam ketentuan regulasi yang telah ditetapkan.

Perubahan Peraturan Pemerintah No.23 Tahun 2005 diperbaharui menjadi PP No. 74 Tahun 2012 yang mulai berlaku pada tanggal 03 September 2012 mengenai Pengelolaan Keuangan Badan Layanan Umum, peraturan pemerintah ini mengatur mengenai persyaratan, penetapan, dan pencabutan status BLU, standar dan tarif layanan, perencanaan dan penganggaran, pengelolaan keuangan, serta pelaporan dan pertanggung-jawaban menjadi dasar sebagai pembentukan Pernyataan SAP No.13 mengenai penyajian laporan keuangan Badan Layanan Umum. Serta memuat isi pada bagian PP No. 71 Tahun 2010, dimana pada bagian tersebut tidak hanya memuat standar akuntansi pemerintahan (SAP) berbasis akrual pada lampiran I namun juga penerapan SAP dari berbasis kas menuju akrual pada lampiran II. Dalam lampiran II SAP berbasis kas menuju akrual, diberlakukan bagi entitas pemerintahan yang belum siap menerapkan.

Menurut Peraturan Menteri Dalam Negeri No.61 Tahun 2007 tentang Pedoman Teknis Pengelolaan Keuangan Badan Layanan Umum Daerah Bab XVII Pasal 116 ayat (1) yang berbunyi: "BLUD menye-lenggarakan akuntansi dan laporan keuangan sesuai dengan Standar Akuntansi Keuangan yang diterbitkan oleh Asosiasi Profesi Akuntansi Indonesia untuk manajemen bisnis yang sehat." Sesuai dengan Per-mendagri ini maka BLUD wajib mengacu pada aturan Pernyataan Standar Akuntansi Pemerintahan Nomor 13 tentang Badan Layanan Umum. Dalam PSAP Nomor 13 berisi mengenai informasi mengenai tujuan pelaporan keuangan BLU, struktur dan isi pelaporan, laporan posisi keuangan, realisasi anggaran, saldo anggaran lebih, arus kas (baik dari sisi aktivitas operasi, investasi, pendanaan), hasil operasi, dan perubahan ekuitas BLU 


\section{JURNAL NOMINAL / VOLUME VIII NOMOR 1 / TAHUN 2019}

yang bermanfaat bagi para pengguna dalam membuat dan mengevaluasi mengenai keputusan alokasi sumber daya.

Pergerakan otonomi daerah yang semakin pesat menyebabkan perubahan paradigma sentralisasi mengarah pada sistem pemerintahan desentralisasi, yang memberikan keleluasaan tiap daerah untuk mewujudkan daerah otonomi yang luas dan bertanggung-jawab sesuai kondisi dan potensi wilayahnya menjadi salah satu alasan kuat adanya penerapan PSAP Nomor 13 tentang penyajian laporan keuangan badan layanan umum dalam masingmasing daerah. Menimbang peraturan PP No.74 Tahun 2012 tersebut merupakan latar belakang dari proses persyaratan Badan Layanan Umum (Daerah), dan menjadi salah satu konsepsi yang hanya dibahas dalam pembentukan BLUD. Untuk dapat menjadi BLUD dalam instansi pemerintahan ada tiga syarat pokok yang harus terpenuhinya dalam instansi tersebut yaitu ; persyaratan teknis berkaitan dengan kinerja pelayanan dan kinerja keuangan, persyaratan sub-stantif yang berkaitan dengan penyelenggaraan umum serta persyaratan administratif yang terkait dengan terpenuhinya dokumen seperti tata kelola, rencana strategis, standar layanan minimal, laporan keuangan pokok, serta dokumen pelaporan audit maupun dokumen bersedia untuk diaudit menjadi syarat yang wajib di penuhi instansi yang tertuang dalam Peraturan Pemerintah No. 61 Tahun 2007.

Puskesmas Tegalrejo Yogyakarta sebagai satuan kerja BLU memiliki kewajiban untuk mematuhi aturan penyusunan laporan keuangan sesuai PSAP No. 13. Sebagai organisasi pusat kesehatan masyarakat, pelayanan kesehatan yang diberikan Puskesmas merupakan pelayanan yang menyeluruh yang meliputi pelayanan kuratif (pengobatan), preventif (pencegahan), promotif (peningkatan kesehatan), dan rehabilitatif (pemulihan kesehatan). Pelayanan tersebut ditujukan kepada semua penduduk dengan tidak membedakan jenis kelamin dan golongan umur. Puskesmas memiliki wilayah kerja yang meliputi satu kecamatan atau sebagian dari kecamatan. Faktor kepadatan penduduk, luas daerah, keadaan geografi, dan keadaan infrastruktur lainnya merupakan bahan pertimbangan dalam menentukan wilayah kerja Puskesmas. Maka dari itu puskesmas merupakan fokus penting dalam subjek penelitian pada proses penerapan PSAP Nomor 13 dalam sistem BLUD yang memberikan dampak kepada kinerja puskesmas, khususnya pada kinerja keuangan dan tata aturan keuangan dalam sistem BLUD.

Analisis kinerja keuangan adalah menilai sejauh mana dampak dari penerapan PSAP Nomor 13 pada sistem BLUD dapat mempengaruhi kinerja 


\section{JURNAL NOMINAL / VOLUME VIII NOMOR 1 / TAHUN 2019}

keuangan dengan menggunakan ukuranukuran rasio dalam meng-analisis kinerja tersebut. Dalam analisis pelaporan keuangan dapat meng-gunakan rasio-rasio keuangan, rasio keuangan adalah metode pengukuran kinerja sebuah organisasi dengan menilik kinerja keuangan atas pelaporan keuangannya dari sebuah organisasi. Rasio Keuangan, berisi komponen alat ukur yang mengukur melalui analisis Rasio Likuiditas, Solvabilitas, Profitabilitas, dan Aktivitas yang akan dibahas lebih lanjut dalam proses analisa laporan keuangan sebelum, transisi dan setelah diterapkannya BLUD. Tujuan yang ingin dicapai dalam penelitian ini adalah sebagai berikut:

(1) Mengetahui analisis Rasio Likuiditas pada Puskesmas Tegalrejo sebelum dan sesudah diterapkannya PSAP Nomor 13, (2) Mengetahui analisis Rasio Solvabilitas pada Puskesmas Tegalrejo sebelum dan sesudah diterapkannya PSAP Nomor 13, (3) Mengetahui analisis Rasio Profitabilitas pada Puskesmas Tegal-rejo sebelum dan sesudah diterap-kannya PSAP Nomor 13, (4) Menge-tahui analisis Rasio Aktivitas pada Puskesmas Tegalrejo sebelum dan sesudah diterapkannya PSAP Nomor 13.

\section{METODE PENELITIAN}

\section{Desain Penelitian}

Desain penelitian yang digunakan adalah penelitian kuantitatif dengan pendekatan deskriptif. Metode pene-litian kuantitatif merupakan salah satu jenis penelitian yang spesifikasinya adalah sistematis, terencana dan ter-struktur dengan jelas sejak awal hingga pembuatan desain penelitiannya. Deskriptif merupakan metode yang memberi gambaran terhadap objek yang diteliti melalui data yang telah terkumpul dalam sebuah penelitian sebagaimana adanya, tanpa melakukan analisis dan membuat kesimpulan yang berlaku umum. Penelitian deskriptif menunjukkan penelitian non hipotesis, sehingga dalam langkah penelitiannya tidak perlu merumuskan hipotesis, selan-jutnya memunculkan pertanyaan permasalahan dalam penelitian seperti dalam penelitian.

\section{Variabel Penelitian}

Variabel dalam penelitian berkaitan dengan alat analisis laporan keuangan sesudah maupun penerapan Pernyataan SAP Nomor 13 dalam sistem Badan Layanan Umum Daerah, yaitu berupa rasio-rasio keuangan yang terdiri atas Rasio Likuiditas, Rasio Solvabilitas, Rasio Profitabilitas, serta Rasio Aktivitas. Subjek penelitian adalah Puskesmas Tegalrejo Yogya-karta. Objek yang diteliti dalam penelitian adalah Laporan Keuangan Puskesmas Tegalrejo Yogyakarta periode 2016-2017. 


\section{JURNAL NOMINAL / VOLUME VIII NOMOR 1 / TAHUN 2019}

Waktu dan Tempat Penelitian

Waktu yang digunakan dalam proses penelitian sekitar 6 bulan, dihitung mulai dari seluruh proses perizinan hingga pengambilan data. Penelitian tersebut menggunakan data historis pada Puskesmas Tegalrejo Yogyakarta.

\section{Subjek dan Objek Penelitian}

Subjek penelitian adalah Puskesmas Tegalrejo Yogyakarta. Objek yang diteliti dalam penelitian adalah Laporan Keuangan Puskesmas Tegalrejo Yogyakarta periode 2016-2017.

Teknik Pengumpulan dan Teknik Analisis Data

\section{Teknik Pengumpulan Data}

Pada penelitian ini teknik pengumpulan data yang digunakan pada penelitian adalah teknik dokumentasi. Menurut Bungrin (2008: 121) teknik dokumentasi adalah salah satu metode pengumpulan data yang digunakan dalam penelitian sosial untuk menelusuri data historis. Penggalian sumber data lewat studi dokumen menjadi proses penelitian kuantitatif.

\section{Teknik Analisis Data}

Metode Analisis dalam penelitian ini menggunakan teknik analisis komparatif sederhana atas Laporan keuangan Puskesmas Tegalrejo sebagai data historis. Penelitian yang mengevaluasi Laporan Keuangan Puskesmas Tegalrejo Yogyakarta sebagai Badan Layanan Umum Daerah diawali dengan analisis komparatif sederhana terhadap subjek penelitian dengan konsep pembanding dalam hal kebijakan akuntansi maupun penyajian laporan keuangan, kemudian mencoba menyesuaikan dan membandingkan antara Laporan Keuangan Puskesmas Tegalrejo Yogyakarta baik sebelum penerapan maupun sesudah penerapan Pernyataan SAP Nomor 13. Dengan asumsi laporan keuangan yang dikeluarkan pada tahun 2016 sebagai laporan keuangan sebelum penerapan PSAP Nomor 13 dan laporan keuangan yang dikeluarkan pada tahun 2017 sebagai laporan keuangan sesudah penerapan PSAP Nomor 13 dalam sistem Badan Layanan Umum Daerah. Alat Analisis menggunakan rasio-rasio keuangan yang dijelaskan oleh Darsono (2005) sebagai berikut,

Menurut Darsono (2005:51), dalam menggunakan alat analisis rasio keuangan, analisis Rasio Likuiditas terdapat didalamnya Rasio Lancar, Quick Test Ratio, Cash Ratio, Net Working Capital, ketika hasil angkanya semakin tinggi menandakan bahwa nilai tersebut baik, (Darsono 2005:52) dalam analisis Defensive Interval Ratio, semakin tinggi hasil angka yang didapatkan, maka analisis liabilitasnya semakin buruk kinerja perusahaan dalam mengembalikan kewajiban jangka pendeknya. Menurut Bambang Riyanto (2010:25) analisis standar baik dalam Rasio Likuiditas jika 


\section{JURNAL NOMINAL / VOLUME VIII NOMOR 1 / TAHUN 2019}

ditinjau dari Rasio Lancar memiliki standar baik >2,0 dan jika ditinjau dari Quick Test Ratio, Cash Ratio memiliki standar baik $>1,0$. Standar baik Rasio Likuiditas jika ditinjau dari Defensive Interval Ratio memiliki nilai standar baik 15 hari jika dianalisis dalam tahap bulanan, dan 183 hari jika dianalisis dalam 1 tahun.

Analisis Rasio Solvabilitas terdiri atas Equity Multiplier, Debt to Equity Ratio, Debt to Asset Ratio, Rasio Utang Jangka Panjang dengan Modal, Rasio Utang dengan Modal, Rasio Utang dengan Aktiva, akan semakin baik ketika hasil angka yang diperoleh semakin kecil (Darsono 2005:54), serta menurut Munawir (2012:82) berbeda dengan analisis rasio solvabilitas dalam Rasio Modal dengan Aktiva, Rasio Modal dengan Aktiva Tetap, Rasio Aktiva Tetap dengan Utang Jangka Panjang, akan semakin baik ketika hasil angka yang didapatkan semakin tinggi. Menurut Lukman (2009:47) standar baik dalam analisis Rasio Solvabilitas jika ditinjau dari Rasio Equity Multiplier, Debt to Equity, Debt to Asset Ratio memiliki nilai standar rasio 0.10-0.50, jika dalam analisis Rasio Solvabilitas yang ditinjau dari Rasio Utang Jangka Panjang dengan Modal, Rasio Utang dengan Modal, Rasio Utang dengan Aktiva, Rasio Modal dengan Aktiva, Rasio Modal dengan Aktiva tetap, Rasio Aktiva Tetap dengan Utang Jangka
Panjang, maka dapat dikatakan relatif baik jika memiliki nilai analisis $>0.50$.

Menurut Darsono (2005:56) dalam analisis Rasio Profitabilitas yang terdiri dari Return on Assets, Perputaran Aktivitas Usaha, Return on Equity, Productivity Ratio, Rentabilitas Modal, akan diperoleh hasil yang semakin tinggi semakin baik, karena semakin tinggi hasil angka rasio profitabilitasnya semakin besar dan baik pula perusahaan memperoleh laba. Dalam analisis Rasio Profitabilitas menurut Bambang Riyanto (2010:35), jika ditinjau dari Return on Asset, Perputaran Aktivitas Usaha, Return on Equity, Productivity Ratio, Rentabilitas Modal akan dikatakan relatif baik ketika memiliki nilai analisis $>1.0$.

Darsono menyatakan (2005:59) dalam analisis Rasio Aktivitas seperti Total Asset Turn Over, Receivable Turn Over, akan mendapatkan hasil analisis terbaik ketika didapati hasil angka yang tinggi karena perusahaan dapat memaksimalkan aktivitas usahanya, (Darsono 2005:59) serta dalam analisis rasio aktivitas atas Rata-rata Penerimaan Piutang dan Working Capital Turnover akan semakin baik ketika hasil angkanya kecil, karena menunjukan semakin kecil kemung-kinan perusahaan merugi. Menurut Lasmi (2017:151) standar baik dalam analisis Rasio Aktivitas jika ditinjau dari Rasio Total Asset Turn Over (TATO), Receivable Turn Over, Working 
Capital Turn Over, dikatakan relatif baik ketika memperoleh nilai standar $>1.0$, jika ditijau dalam analisis Rasio Aktivitas atas Rata-rata Penerimaan Piutang dikatakan relatif baik jika memperoleh analisis nilai 10-15 hari.

\section{HASIL DAN PEMBAHASAN}

Hasil penelitian yang dianalisis menggunakan alat analisis rasio keuangan yaitu; Rasio Likuiditas, Rasio Solvabilitas, Rasio Profitabilitas, dan Rasio Aktivitas pada Pelaporan Keuangan Puskesmas Tegalrejo pada tahun 2016 dan 2017, Maka diperoleh hasil sebagai berikut;

\begin{tabular}{|c|c|c|c|c|}
\hline \multirow{2}{*}{$\begin{array}{c}\text { Rasio } \\
\text { Keuan } \\
\text { gan }\end{array}$} & \multicolumn{2}{|c|}{$\begin{array}{c}\text { Hasil Analisis } \\
\text { Rasio Keuangan }\end{array}$} & \multirow{2}{*}{$\begin{array}{c}\text { Hasil } \\
\text { Keterba } \\
\text { ndingan }\end{array}$} & \multirow[t]{2}{*}{$\begin{array}{l}\text { Kate } \\
\text { gori }\end{array}$} \\
\hline & $\begin{array}{c}\text { Tahun } \\
2016\end{array}$ & $\begin{array}{c}\text { Tahun } \\
2017\end{array}$ & & \\
\hline
\end{tabular}

\begin{tabular}{|c|c|c|c|c|}
\hline \multicolumn{5}{|c|}{ A.Rasio Likuiditas } \\
\hline \multirow{5}{*}{$\begin{array}{l}\text { 1. Rasi } \\
\text { o } \\
\text { Lanca } \\
\text { r }\end{array}$} & 2.05597 & 0.5901 & Turun & Relat \\
\hline & 2453 & 94879 & & \\
\hline & & & & Kura \\
\hline & & & & ng \\
\hline & & & & Baik \\
\hline \multirow{3}{*}{$\begin{array}{l}\text { 2. Qui } \\
\text { ck Test } \\
\text { Ratio }\end{array}$} & 1.84112 & 1.9923 & Naik & Relat \\
\hline & 221 & 45519 & & \\
\hline & & & & Baik \\
\hline \multirow{5}{*}{$\begin{array}{l}\text { 3. Cash } \\
\text { Ratio }\end{array}$} & 1.43514 & 0.8653 & Turun & Relat \\
\hline & 183 & 34896 & & \\
\hline & & & & Kura \\
\hline & & & & $\mathrm{ng}$ \\
\hline & & & & Baik \\
\hline \multirow{5}{*}{$\begin{array}{l}\text { 4. Net } \\
\text { Work } \\
\text { ing } \\
\text { Capit } \\
\text { al } \\
\end{array}$} & 1.05597 & 0.8932 & Turun & Relat \\
\hline & 2453 & 17493 & & if \\
\hline & & & & Kura \\
\hline & & & & ng \\
\hline & & & & Baik \\
\hline \multirow{5}{*}{$\begin{array}{l}\text { 5. Defe } \\
\quad \text { nsive } \\
\quad \text { Interv } \\
\quad \text { al } \\
\quad \text { Ratio }\end{array}$} & 38 Hari & 48 & & Relat \\
\hline & & Hari & & if \\
\hline & & & & Kura \\
\hline & & & & ng \\
\hline & & & & Baik \\
\hline
\end{tabular}

B. Rasio Solvabilitas

\begin{tabular}{|c|c|c|c|c|}
\hline $\begin{array}{l}\text { 1. Equ } \\
\text { ity } \\
\text { Multi } \\
\text { plier }\end{array}$ & $\begin{array}{l}1.24915 \\
5345\end{array}$ & $\begin{array}{l}1.2208 \\
94039\end{array}$ & Turun & $\begin{array}{l}\text { Relat } \\
\text { if } \\
\text { Baik }\end{array}$ \\
\hline $\begin{array}{l}\text { 2. Deb t } \\
\text { to } \\
\text { Equity }\end{array}$ & $\begin{array}{l}0.19945 \\
9055\end{array}$ & $\begin{array}{l}0.1809 \\
2754\end{array}$ & Turun & $\begin{array}{l}\text { Relat } \\
\text { if } \\
\text { Baik }\end{array}$ \\
\hline $\begin{array}{l}\text { 3. Deb } t \\
\text { to } \\
\text { Asset } \\
\text { Ratio }\end{array}$ & $\begin{array}{l}0.24915 \\
5345\end{array}$ & $\begin{array}{l}0.2208 \\
93355\end{array}$ & Turun & $\begin{array}{l}\text { Relat } \\
\text { if } \\
\text { Baik }\end{array}$ \\
\hline $\begin{array}{l}\text { 4. Ras } \\
\text { io } \\
\text { Utang } \\
\text { Jangk } \\
\text { a } \\
\text { Panja } \\
\text { ng } \\
\text { denga } \\
\text { n } \\
\text { Moda } \\
\text { l }\end{array}$ & 0 & 0 & Tetap & $\begin{array}{l}\text { Relat } \\
\text { if } \\
\text { Baik }\end{array}$ \\
\hline $\begin{array}{l}\text { 5. Ras } \\
\text { io } \\
\text { Utang } \\
\text { denga } \\
\text { n } \\
\text { Moda } \\
\text { l } \\
\end{array}$ & $\begin{array}{l}0.24915 \\
5345\end{array}$ & $\begin{array}{l}0.2208 \\
93355\end{array}$ & Turun & $\begin{array}{l}\text { Relat } \\
\text { if } \\
\text { Baik }\end{array}$ \\
\hline $\begin{array}{l}\text { 6. Ra } \\
\text { sio } \\
\text { Utang } \\
\text { denga } \\
\text { n } \\
\text { Aktiv } \\
\text { a } \\
\end{array}$ & $\begin{array}{l}0.19945 \\
9055\end{array}$ & $\begin{array}{l}0.1809 \\
2754\end{array}$ & Turun & $\begin{array}{l}\text { Relat } \\
\text { if } \\
\text { Baik }\end{array}$ \\
\hline $\begin{array}{l}\text { 7. Ra } \\
\text { sio } \\
\text { Moda } \\
\text { l } \\
\text { denga } \\
\text { n } \\
\text { Aktiv } \\
\text { a } \\
\end{array}$ & $\begin{array}{l}0.80054 \\
0945\end{array}$ & $\begin{array}{l}0.8190 \\
719\end{array}$ & Naik & $\begin{array}{l}\text { Relat } \\
\text { if } \\
\text { Baik }\end{array}$ \\
\hline $\begin{array}{l}\text { 8. Ras } \\
\text { io } \\
\text { Moda } \\
\text { l } \\
\text { denga } \\
\text { n } \\
\text { Aktiv } \\
\text { a } \\
\text { Tetap } \\
\end{array}$ & $\begin{array}{l}1.35953 \\
9626\end{array}$ & $\begin{array}{l}1.7184 \\
45783\end{array}$ & Naik & $\begin{array}{l}\text { Relat } \\
\text { if } \\
\text { Baik }\end{array}$ \\
\hline $\begin{array}{l}\text { 9. Ras io } \\
\text { Aktiv } \\
\text { a } \\
\text { Tetap } \\
\text { denga } \\
\text { n } \\
\text { Utang }\end{array}$ & 0 & $\mathbf{0}$ & Tetap & $\begin{array}{l}\text { Relat } \\
\text { if } \\
\text { Baik }\end{array}$ \\
\hline
\end{tabular}


JURNAL NOMINAL / VOLUME VIII NOMOR 1 / TAHUN 2019

\begin{tabular}{|c|c|c|c|c|}
\hline \multicolumn{5}{|l|}{$\begin{array}{l}\text { Jangk } \\
\text { a } \\
\text { Panja } \\
\text { ng }\end{array}$} \\
\hline \multicolumn{5}{|c|}{ C.Rasio Profitabilitas } \\
\hline $\begin{array}{l}\text { 1. Ret } \\
\text { urn } \\
\text { on } \\
\text { Assets }\end{array}$ & $\begin{array}{l}(0.2363 \\
07833)\end{array}$ & $\begin{array}{l}\text { 0.0279 } \\
79415\end{array}$ & Naik & $\begin{array}{l}\text { Relat } \\
\text { if } \\
\text { Baik }\end{array}$ \\
\hline $\begin{array}{l}\text { 2. Per } \\
\text { pu } \\
\text { taran } \\
\text { Aktivi } \\
\text { tas } \\
\text { Usaha }\end{array}$ & $\begin{array}{l}3.28412 \\
6352\end{array}$ & $\begin{array}{l}3.5587 \\
37493\end{array}$ & Naik & $\begin{array}{l}\text { Relat } \\
\text { if } \\
\text { Baik }\end{array}$ \\
\hline $\begin{array}{l}\text { 3. Ret } \\
\text { urn } \\
\text { on } \\
\text { Equity }\end{array}$ & $\begin{array}{l}(0.2951 \\
85193)\end{array}$ & $\begin{array}{l}0.0341 \\
59901\end{array}$ & Naik & $\begin{array}{l}\text { Relat } \\
\text { if } \\
\text { Baik }\end{array}$ \\
\hline $\begin{array}{l}\text { 4. Pro } \\
\text { ductiv } \\
\text { ity } \\
\text { Ratio }\end{array}$ & $\begin{array}{l}3.25399 \\
518\end{array}$ & $\begin{array}{l}2.5358 \\
7578\end{array}$ & Turun & $\begin{array}{l}\text { Relat } \\
\text { if } \\
\text { Kura } \\
\text { ng } \\
\text { Baik }\end{array}$ \\
\hline $\begin{array}{l}\text { 5. Ren } \\
\text { tabilit } \\
\text { as } \\
\text { Moda } \\
\text { l }\end{array}$ & $\begin{array}{l}4.10238 \\
3985\end{array}$ & $\begin{array}{l}4.3448 \\
41392\end{array}$ & Naik & $\begin{array}{l}\text { Relat } \\
\text { if } \\
\text { Kura } \\
\text { ng } \\
\text { Baik }\end{array}$ \\
\hline D.Rasic & Aktivitas & & & \\
\hline $\begin{array}{l}\text { 1. Tot al } \\
\text { Asset } \\
\text { Turn } \\
\text { Over }\end{array}$ & $\begin{array}{l}(0.2363 \\
07833)\end{array}$ & $\begin{array}{l}0.0279 \\
79415\end{array}$ & Naik & $\begin{array}{l}\text { Relat } \\
\text { if } \\
\text { Baik }\end{array}$ \\
\hline $\begin{array}{c}\text { 2. Rece } \\
\text { ivable } \\
\text { Turn } \\
\text { Over }\end{array}$ & $\begin{array}{l}145.819 \\
5228\end{array}$ & $\begin{array}{l}87.737 \\
6942\end{array}$ & Turun & $\begin{array}{l}\text { Relat } \\
\text { if } \\
\text { Kura } \\
\text { ng } \\
\text { Baik }\end{array}$ \\
\hline $\begin{array}{l}\text { 3. Rasio } \\
\text { Aktivi } \\
\text { tas } \\
\text { atas } \\
\text { Rata- } \\
\text { rata } \\
\text { Pener } \\
\text { imaan } \\
\text { Piuta } \\
\text { ng } \\
\end{array}$ & $\begin{array}{l}2.50309 \\
4188\end{array}$ & $\begin{array}{l}4.1601 \\
27564\end{array}$ & Naik & $\begin{array}{l}\text { Relat } \\
\text { if } \\
\text { Kura } \\
\text { ng } \\
\text { Baik }\end{array}$ \\
\hline $\begin{array}{l}\text { 4. Wor } \\
\text { king } \\
\text { Capital } \\
\text { Turnov } \\
\text { er }\end{array}$ & $\begin{array}{l}4.10238 \\
3985\end{array}$ & $\begin{array}{l}4.3448 \\
41392\end{array}$ & Naik & $\begin{array}{l}\text { Relat } \\
\text { if } \\
\text { Kura } \\
\text { ng } \\
\text { Baik }\end{array}$ \\
\hline
\end{tabular}

Tabel 1. Hasil Analisis Pembanding

Rasio Keuangan Pada Penyajian Laporan
Keuangan Puskesmas Tegalrejo

Yogyakarta

Dalam analisis pembanding rasio keuangan yang didalamnya terdapat analisis Rasio Likuiditas, Rasio Solvabilitas, Rasio Profitabilitas, serta Rasio Aktivitas terhadap penyajian laporan keuangan Puskesmas Tegalrejo Kota Yogyakarta yang dikeluarkan tahun 2016 sebagai laporan keuangan sebelum penerapan sistem Badan Layanan Umum Daerah, dan laporan keuangan yang dikeluarkan tahun 2017 sebagai laporan keuangan setelah penerapan sistem Badan Layanan Umum Daerah, maka dapat diketahui bahwa secara umum menilai hasil pembanding Rasio Likuiditas dan Rasio Aktivitas cenderung mengalami kondisi pembandingan yang relatif kurang baik, yang berarti dalam analisis banding rasio tersebut di tahun 2017 memiliki tingkat Rasio Likuiditas dan Rasio Aktivitas yang lebih rendah dari laporan keuangan yang keluar tahun 2016. Dalam analisis Rasio Solvabilitas serta Rasio Profitabilitas ditinjau secara umum pembanding laporan keuangan maka Rasio Solvabilitas dan Rasio Profitabilitas mengalami perbandingan relatif baik daripada tahun dasar, yang berarti bahwa laporan keuangan ditahun 2016 sebagai dasar sebelum penerapan sistem BLU lebih rendah atau relatif kurang baik dari pada pelaporan keuangan yang dikeluarkan tahun 2017 


\section{JURNAL NOMINAL / VOLUME VIII NOMOR 1 / TAHUN 2019}

sebagai pelaporan setelah diterapkannya sistem Badan Layanan Umum.

Secara khusus dalam analisis Rasio Likuiditas pada perhitungan Rasio Lancar. Cash Ratio, Net Working Capital, Defensive Interval Ratio, cenderung relatif kurang baik dalam analisis rasionya membuktikan bahwa Puskesmas Tegalrejo memiliki tingkat likuiditas yang relatif kurang baik, hasil perhitungan analisis Rasio Likuiditas yang relatif kurang baik didukung dengan adanya penururnan aset/aktiva lancar, serta menurunya akun kas setara kas pada Puskesmas Tegalrejo Yogyakarta.

Analisis Rasio Likuiditas juga sering disebutkan sejauh mana kemampuan perusahaan mencairkan seluruh kepemilikan perusahaan jika di likuidasi serta perusahaan dapat memenuhi kewajiban secara tepat waktu, maka analisis Rasio Likuiditas dinilai relatif kurang baik serta pemenuhan kewajiban secara tepat waktu Puskesmas Tegalrejo cenderung relatif kurang baik. Menurut Munawir (2012:31) perusahaan dikatakan mampu memenuhi kewajiban keuangan tepat pada waktunya apabila per-usahaan tersebut mempunyai alat pembayaran ataupun aktiva lancar yang lebih besar daripada hutang lancar atau hutang jangka pendeknya, sebaliknya kalau perusahaan tidak dapat segera memenuhi kewajiban keuangannya pada saat ditagih, berarti perusahaan tersebut dalam keadaan illikuiditas. Namun analisis Rasio Likuiditas dalam Quick Test Ratio menunjukkan hasil pembanding yang baik mengingat adanya peningkatan investasi jangka pendek, serta meningkatnya piutang perusahaan sangat berpengaruh kepada perusahaan, terdapatnya penurunan kewajiban lancar serta kas dari tahun 2016 sampai 2017 mempengaruhi hasil perhitungan Quick Test Ratio, namun hasil tersebut tidak berperan besar dalam analisis Rasio Likuiditas lainnya yang cenderung relatif kurang baik.

Hasil analisis Rasio Solvabilitas dalam Rasio Equity Multiplier, Debt to Equity, Debt to Asset Ratio, Rasio Utang dengan Modal, Rasio Utang dengan Aktiva, secara analisis perbandingan mengalami penurunan yang artinya dalam rasio tersebut relatif baik adanya dari pelaporan keuangan tahun 2016 dan pelaporan keuangan 2017, dan dalam perhitungan analisis Rasio Modal dengan Aktiva, Rasio Modal dengan Aktiva tetap, Rasio Aktiva Tetap mengalami peningkatan dari tahun 2016 hingga 2017 yang artinya dalam analisis rasio tersebut juga relatif baik adanya.

Analisis Rasio Solvabilitas dalam Rasio Utang Jangka Panjang dengan Modal serta Rasio Aktiva Tetap dengan Utang Jangka Panjang menghasilkan angka yang tidak signifikan mengingat tidak adanya 


\section{JURNAL NOMINAL / VOLUME VIII NOMOR 1 / TAHUN 2019}

Utang Jangka Panjang dalam analisis rasio tersebut dan menghasilkan nilai nol bulat untuk Rasio Utang Jangka Panjang dengan Modal dan analisis Rasio Aktiva Tetap dengan Utang Jangka Panjang. Hasil yang relatif baik terhadap analisis Rasio Solvabilitas pada Puskesmas Tegalrejo didukung dengan adanya penurunan utang jangka pendek, menurunya kewajiban total, serta tidak adanya hutang jangka panjang dari kegiatan Puskesmas Tegalrejo Yogyakarta, hasil analisis tersebut telah menggambarkan bahwa Puskesmas Tegalrejo memiliki nilai Rasio Solvabilitas yang relatif baik, artinya menunjuk kemampuan Puskesmas Tegalrejo untuk memenuhi kewajiban keuangannya apabila perusahaan dilikuidasi baik kewajiban keuangan jangka pendek maupun keuangan jangka panjang. Dalam hasil yang diperoleh pada analisis rasio keuangan pada Puskesmas Tegalrejo menurut Munawir (2012:32), hubungan antara Rasio Likuiditas dan Rasio Solvabilitas mengalami keadaan perusahaan yang illikuid tetapi solvabel.

Hasil analisis menggunakan Rasio Profitabilitas menunjukan hasil analisis yang meningkat, artinya kemampuan perusahaan dalam mencari keuntungan memiliki hasil yang relatif baik. Rasio ini juga memberikan ukuran tingkat efektivitas manajemen suatu peru-sahaan, analisis lebih lanjut dalam Rasio Profitabilitas bahwa rasio Return on Assets, Perputaran Aktivitas Usaha, Return on Equity, serta Rentabilitas Modal, mendapatkan hasil yang meningkat seiring meningkatnya kemampuan perusahaan dalam mencari pendapatan dalam Puskesmas Tegalrejo Yogyakarta sebagai Badan Layanan Umum Daerah. Hasil analisis Rasio Profitabilitas yang baik didukung dengan defisitnya laporan operasional pada Puskesmas Tegalrejo di tahun 2016, dan meningkat atau Surplus ditahun 2017, serta didukung dengan meningkatnya akun pendapatan pada Puskesmas Tegalrejo Yogyakarta. Beda halnya dengan hasil analisis Productivity Ratio, perhitungan rasio tersebut menunjukan penurunan, mengingat Productivity Ratio dihitung berdasarkan pendapatan, hal tersebut berpengaruh terhadap perhitungan, namun yang terjadi pada Puskesmas Tegalrejo Yogyakarta memiliki pengaruh peningkatan pendapatan yang tidak terlalu banyak dari tahun 2016 hingga 2017, diikuti dengan peningkatan nilai rata-rata aktiva yang dimiliki oleh Puskesmas Tegalrejo yang mengakibatkan hasil perhitungan dari tahun 2017 menurun dari Productivity Ratio di tahun 2016.

Hasil perhitungan Rasio Aktivitas menunjukan bahwa analisis Rasio Aktivitas memiliki hasil nilai yang menurun dari penyajian laporan keuangan Puskesmas Tegalrejo dari tahun 2016 serta laporan 


\section{JURNAL NOMINAL / VOLUME VIII NOMOR 1 / TAHUN 2019}

keuangan Puskesmas Tegalrejo yang dikeluarkan Tahun 2017. Hasil analisis rasio yang menurun didukung dengan peningkatan pendapatan yang tidak terlalu banyak dari tahun 2016 hingga tahun 2017 namun diikuti peningkatan piutang yang besar dari tahun 2017 setelah penerapan sistem BLUD. Hasil perhitungan yang menurun menunjukan bahwa penggunaan aktiva dalam Puskesmas Tegalrejo Yogyakarta kurang efektif, atau penggunaan sumber daya perusahaan kurang efisien. Dalam analisis lebih lanjut rasio aktivitas yaitu rasio Receivable Turn Over, Rasio aktivitas atas Rata-rata Penerimaan Piutang, Working Capital Turnover memiliki hasil perhitungan yang menurun dan telah menggambarkan keseluruhan analisis rasio aktivitas mengalami penurunan yang berarti kurang efektif dan efisiennya Puskesmas Tegalrejo dalam menggunakan aktiva ataupun sumber daya yang dimiliki.

Ditinjau dari Rasio Likuiditas diperoleh, Rasio Lancar tahun 2016 memperoleh hasil 2.05 (baik) sedangkan di tahun 2017 memperoleh hasil 0.59 (kurang baik), Cash Ratio tahun 2016 memperoleh hasil 1.43 (baik) sedangkan di tahun 2017 memperoleh hasil 0.86 (kurang baik), Net Working Capital tahun 2016 memperoleh hasil 1.05 (baik) sedangkan di tahun 2017 memperoleh hasil 0.40 (kurang baik), Defensive Interval Ratio tahun 2016 memperoleh hasil 38 hari (baik) sedangkan di tahun 2017 memperoleh hasil 48 hari (kurang baik), yang artinya hasil perbandingan rasio keuangan tahun 20162017 relatif kurang baik, serta Rasio Likuiditas yang ditinjau dari Quick Test Ratio relatif lebih baik dalam hasil perbandingan, di tahun 2016 memperoleh hasil 1.84 (baik) sedangkan di tahun 2017 memperoleh hasil 1.99 (baik).

Ditinjau dari Rasio Solvabilitas diperoleh, Rasio Equity Multiplier di tahun 2016 memperoleh hasil 1.24 (baik) sedangkan di tahun 2017 memperoleh hasil 1.22 (baik), Debt to Equity di tahun 2016 memperoleh hasil 0.19 (baik) sedangkan di tahun 2017 memperoleh hasil 0.18 (baik), Debt to Asset Ratio di tahun 2016 memperoleh hasil 0.19 (baik) sedangkan di tahun 2017 memperoleh hasil 0.18 (baik), Rasio Utang dengan Modal di tahun 2016 memperoleh hasil 0.24 (kurang baik) sedangkan di tahun 2017 memperoleh hasil 0.22 (kurang baik), Rasio Utang dengan Aktiva di tahun 2016 memperoleh hasil 0.19 (kurang baik) sedangkan di tahun 2017 memperoleh hasil 0.18 (kurang baik), Rasio Modal dengan Aktiva di tahun 2016 memperoleh hasil 0.80 (baik) sedangkan di tahun 20170.81 (baik), jika ditinjau dari Rasio Modal dengan Aktiva Tetap di tahun 2016 memperoleh hasil 1.35 (kurang baik) sedangkan di tahun 2017 memperoleh hasil 1.71 (kurang baik), yang artinya Rasio 


\section{JURNAL NOMINAL / VOLUME VIII NOMOR 1 / TAHUN 2019}

Solvabilitas memperoleh hasil perbandingan rasio keuangan tahun 20162017 relatif baik, jika Rasio Solvabilitas ditinjau dari Rasio Utang Jangka Panjang dengan Modal dan Rasio Aktiva Tetap dengan Utang Jangka Panjang, maka Rasio Utang Jangka Panjang memperoleh hasil 0 di tahun 2016 maupun 2017, sedangkan Rasio Aktiva Tetap dengan Utang Jangka Panjang memperoleh hasil 0 dalam analisis laporan keuangan di tahun 2016 dan 2017.

Ditinjau dari Rasio Profitabilitas diperoleh, Return on Assets di tahun 2016 memperoleh hasil (0.23) (kurang baik) sedangkan di tahun 2017 memperoleh hasil 0.02 (kurang baik), Perputaran Aktivitas Usaha di tahun 2016 memperoleh hasil 3.28 (baik) sedangkan di tahun 2017 memperoleh hasil 3.55 (baik), Return on Equity di tahun 2016 memperoleh hasil (0.29) (kurang baik) sedangkan di tahun 2017 memperoleh hasil 0.03 (kurang baik), Rentabilitas Modal di tahun 2016 memperoleh hasil 4.10 (baik) sedangkan di tahun 2017 memperoleh hasil 4.34 (baik), yang artinya hasil perbandingan rasio keuangan tahun 2016-2017 relatif baik, sedangkan Rasio Profitabilitas jika ditinjau dari Productivity Ratio memperoleh hasil menurun yang berarti hasil perbandingan relatif kurang baik, di tahun 2016 memperoleh hasil 3.25 (baik) sedangkan di tahun 2017 memperoleh hasil 2.53 (baik).
Ditinjau dari Rasio Aktivitas diperoleh, Receivable Turn Over di tahun 2016 memperoleh hasil 145.81 (baik) sedangkan di tahun 2017 memperoleh hasil 87.73 (baik), Rasio aktivitas atas Rata-rata Penerimaan Piutang di tahun 2016 memperoleh hasil 2.50 hari (baik) sedangkan di tahun 2017 memperoleh hasil 4.16 hari (baik), Working Capital Turnover di tahun 2016 mendapatkan hasil 4.10 (baik) sedangkan di tahun 2017 memperoleh hasil 4.34 (baik), sedangkan Rasio Aktivitas jika ditinjau dari Rasio Total Asset Turn Over (TATO) di tahun 2016 memperoleh hasil (0.23) (kurang baik) sedangkan di tahun 2017 memperoleh hasil 0.02 (kurang baik), yang artinya hasil pembanding rasio keuangan tahun 20162017 relatif baik.

\section{SIMPULAN DAN SARAN}

\section{Simpulan}

a) Ditinjau dari Rasio Likuiditas diperoleh; Rasio Lancar tahun 2016 memperoleh hasil 2.05 (baik) sedangkan di tahun 2017 memperoleh hasil 0.59 (kurang baik), Cash Ratio tahun 2016 memperoleh hasil 1.43 (baik) sedangkan di tahun 2017 memperoleh hasil 0.86 (kurang baik), Net Working Capital tahun 2016 memperoleh hasil 1.05 (baik) sedangkan di tahun 2017 mem-peroleh hasil 0.40 (kurang baik), Defensive Interval Ratio 


\section{JURNAL NOMINAL / VOLUME VIII NOMOR 1 / TAHUN 2019}

tahun 2016 memperoleh hasil 38 hari (baik) sedangkan di tahun 2017 memperoleh hasil 48 hari (kurang baik), yang artinya hasil perbandingan rasio keuangan tahun 2016-2017 relatif kurang baik, serta Rasio Likuiditas yang ditinjau dari Quick Test Ratio relatif lebih baik dalam hasil perbandingan, di tahun 2016 memperoleh hasil 1.84 (baik) sedangkan di tahun 2017 memperoleh hasil 1.99 (baik).

b) Ditinjau dari Rasio Solvabilitas diperoleh; Rasio Equity Multiplier di tahun 2016 memperoleh hasil 1.24 (baik) sedangkan di tahun 2017 memperoleh hasil 1.22 (baik), Debt to Equity di tahun 2016 memperoleh hasil 0.19 (baik) sedangkan di tahun 2017 memperoleh hasil 0.18 (baik), Debt to Asset Ratio di tahun 2016 memperoleh hasil 0.19 (baik) sedangkan di tahun 2017 memperoleh hasil 0.18 (baik), Rasio Utang dengan Modal di tahun 2016 mem-peroleh hasil 0.24 (kurang baik) sedangkan di tahun 2017 memperoleh hasil 0.22 (kurang baik), Rasio Utang dengan Aktiva di tahun 2016 mem-peroleh hasil 0.19 (kurang baik) sedangkan di tahun 2017 memperoleh hasil 0.18 (kurang baik), Rasio Modal dengan Aktiva di tahun 2016 mem-peroleh hasil 0.80 (baik) sedangkan di tahun 20170.81 (baik), jika ditinjau dari Rasio Modal dengan
Aktiva Tetap di tahun 2016 memperoleh hasil 1.35 (kurang baik) sedangkan di tahun 2017 memperoleh hasil 1.71 (kurang baik), yang artinya Rasio Solvabilitas memperoleh hasil perban-dingan rasio keuangan tahun 2016-2017 relatif baik, jika Rasio Solvabilitas ditinjau dari Rasio Utang Jangka Panjang dengan Modal dan Rasio Aktiva Tetap dengan Utang Jangka Panjang, maka Rasio Utang Jangka Panjang memperoleh hasil 0 di tahun 2016 maupun 2017, sedangkan Rasio Aktiva Tetap dengan Utang Jangka Panjang mem-peroleh hasil 0 dalam analisis laporan keuangan di tahun 2016 dan 2017.

c) Ditinjau dari Rasio Profitabilitas diperoleh; Return on Assets di tahun 2016 mem-peroleh hasil (0.23) (kurang baik) sedangkan di tahun 2017 memperoleh hasil 0.02 (kurang baik), Perputaran Aktivitas Usaha di tahun 2016 mem-peroleh hasil 3.28 (baik) sedangkan di tahun 2017 mem-peroleh hasil 3.55 (baik), Return on Equity di tahun 2016 memperoleh hasil (0.29) (kurang baik) sedangkan di tahun 2017 memperoleh hasil 0.03 (kurang baik), Rentabilitas Modal di tahun 2016 memperoleh hasil 4.10 (baik) sedangkan di tahun 2017 memperoleh hasil 4.34 (baik), yang artinya hasil perbandingan rasio keuangan tahun 


\section{JURNAL NOMINAL / VOLUME VIII NOMOR 1 / TAHUN 2019}

2016-2017 relatif baik, sedangkan

Rasio Profitabilitas jika ditinjau dari Productivity Ratio memperoleh hasil menurun yang berarti hasil perbandingan relatif kurang baik, di tahun 2016 memperoleh hasil 3.25 (baik) sedangkan di tahun 2017 memperoleh hasil 2.53 (baik).

d) Ditinjau dari Rasio Aktivitas diperoleh; Receivable Turn Over di tahun 2016 memperoleh hasil 145.81 (baik) sedangkan di tahun 2017 memperoleh hasil 87.73 (baik), Rasio aktivitas atas Rata-rata Penerimaan Piutang di tahun 2016 memperoleh hasil 2.50 hari (baik) sedangkan di tahun 2017 memperoleh hasil 4.16 hari (baik), Working Capital Turnover di tahun 2016 mendapatkan hasil 4.10 (baik) sedangkan di tahun 2017 memperoleh hasil 4.34 (baik), sedangkan Rasio Aktivitas jika ditinjau dari Rasio Total Asset Turn Over (TATO) di tahun 2016 memperoleh hasil (0.23) (kurang baik) sedangkan di tahun 2017 memperoleh hasil 0.02 (kurang baik), yang artinya hasil pembanding rasio keuangan tahun 2016-2017 relatif baik.

\section{Saran}

a) Puskesmas Tegalrejo Yogya-karta dapat terus meneruskan asas kontinuitasnya dalam menerapkan
PSAP Nomor 13 dalam penyajian laporan keuangannya.

b) Puskesmas Tegalrejo meleng-kapi asas-asas keterbukaan atas pelaporan keuangan, mengingat BLUD merupakan sistem yang transparansif dan terbuka namun menutup hal-hal yang menjadi rahasia Puskesmas

c) Puskesmas Tegalrejo juga harus menilai sejauh mana Piutang Usaha atas keterbukaan dalam mencari dan mengajak pasien tanpa mengabaikan kepentingan utama pelayanan.

d) Jika adaya perbaikan atas peraturan penyajian laporan keuangan mengenai Badan Layanan Umum Daerah maka Puskesmas Tegalrejo diharap-kan segera memperbaiki dan memperbarui cara penyajian laporan keuangannya.

\section{DAFTAR PUSTAKA}

Amelia, Meyrisa. (2014). Analisis Tingkat Pemahaman Aparatur Pemerintah Mengenai PSAP No. 12 Laporan Operasional Jurnal. Bandung: UPI

Bastian, Indra. (2010). Akuntansi Sektor Publik. Jakarta: Erlangga

Darsono dan Ashari. (2005). Pedoman Praktis Memahami Laporan Keuangan. Yogyakarta: Andi

Gunawan, Imam. (2013). Metode Penelitian Kualitatif Teori \& Praktik. Jakarta: Bumi Aksara 


\section{JURNAL NOMINAL / VOLUME VIII NOMOR 1 / TAHUN 2019}

Halim, Abdul. (2017). Akuntansi Sektor Publik. Jakarta: Salemba Empat.

Kementrian Pekerjaan Umum. (2016). Pedoman Administrasi Penerapan Pengelolaan Keuangan BLUD. Jakarta: Direktorat Jenderal Cipta Karya

Kaplan, Robert. S dan Norton. (2000). Balance Scorecard Menerapkan Strategi Menjadi Aksi. Jakarta: Erlangga

Kawenas, Riani Isye, dkk. (2016). Analsis Penerapan PSAP Nomor 13 Tentang Penyajian Laporan Keuangan Badan Layanan Umum Pada RSUP. Prof. Dr. $R$. D. Kandou Manado Jurnal. Manado: Universitas Sam Ratulangi.

Lambey, Robert. (2015). Analisis Penerapan PSAP No. 07 Tentang Akuntansi Aset Tetap Pada Balai Lanjut Usia "Senja Cerah" Jurnal. Manado: Universitas Sam Ratulangi.

Lasmi, Mia. (2017). Analisis Laporan Keuangan. Bandung: CV Pustaka Setia

Mardiasmo. (2009). Akuntansi Sektor Publik. Yogyakarta: Andi

Mamang, Etta Sangaji, dan Sopiah. (2010). Metodologi Penelitian. Yogyakarta: Andi

Priadana, Sidik dan Muis Saludin. (2009). Metode Penelitian Ekonomi \& Bisnis. Yogyakarta: Graha Ilmu

Peraturan Pemerintah Republik Indonesia Nomor 71 Tahun 2010

Peraturan Mentri Dalam Negeri Nomor 61 Tahun 2010

Pernyataan Standar Akuntansi Pemerintah Nomor 13 Tahun 2016
Riyanto, Bambang. (2010). Dasar Dasar Pembelanjaan Perusahaan. Yogyakarta: BPFE

Sugiyono, (2010). Metode Penelitian Kuantitatif Kualitatif dan $R \& D$. Bandung: Alfabeta

Syamsudin, Lukman. (2009). Manajemen Keuangan Perusahaan. Jakarta: Rajawali Pres

WEB http://www.ksap.org/sap/wpcontent/uploads/2016/02/PSAP-13PLK-BLU-Ver-KSAP-final.pdf diakses pada tanggal 05 Desember 2017, Pukul 14.00 WIB

WEB http://www.wikiapbn.org/stan darakuntansi-pemerintahan/ diakses pada tanggal 12 Desember 2017, Pukul 14.00 WIB

WEB http://lib.unnes.ac.id/22251/1/ 7311411105-s.pdf diakses pada tanggal 12 Desember 2017, Pukul $\underline{15.40 \mathrm{WIB}}$

WEB http://www.uangkartal.com/20 16/03/psap-13-produk-ksapterbaru-yang.html diakses pada tanggal 14 Desember 2017, Pukul $08.00 \mathrm{WIB}$

WEB http://ciptakarya.pu.go.id/plp/ upload/peraturan/PEDOMAN_AD MINISTRASI_PENERAPAN_PENG ELOLAAN_KEUANGAN_BLUD.pd $f$ diakses pada tanggal 14 Desember 2017, Pukul 09.00 WIB

WEB repositori.ugm.ac.id/UPTD-BLUD diakses pada tanggal 18 Desember 2017, Pukul 12.00 WIB ,. (2010). Standar

Akuntansi Pemerintahan. Salemba Empat:Jakarta 